\title{
A Quantitative and Qualitative Analysis of Antioxidant Enzymes in Relation to Susceptibility of Apples to Superficial Scald
}

\author{
Sunita Kochhar ${ }^{1}$ and Christopher B. Watkins ${ }^{2}$ \\ Department of Horticulture, Cornell University, Ithaca, NY 14853 \\ Patricia L. Conklin \\ Department of Biological Sciences, SUNY-Cortland, 364 Bowers Hall, Cortland, NY 13045 \\ Susan K. Brown
Department of Horticultural Sciences, Cornell University, New York Agricultural Experiment Station,
Geneva, NY 14456
}

ADDITIONAL INDEX WORDS. postharvest physiology, storage, physiological disorder, Malus

\begin{abstract}
The activities and isoenzyme patterns of guaiacol-dependent peroxidase (POX), ascorbate peroxidase (APX), superoxide dismutase (SOD) and catalase (CAT) were studied in yellow- and red-fruited crab apple [Malus (L.) Mill.] selections from a 'White Angel' x 'Rome Beauty' cross that show differential susceptibility to the physiological storage disorder, superficial scald. There were no consistent relationships between total enzyme activities and scald incidence, high activities of the enzymes being detected in selections with both high and low susceptibilities to scald. However, additional individual isoforms of some antioxidant enzymes were detected in the scald-resistant selections when compared with scald-susceptible selections. In a native gel system, four guaiacol-dependent POX isoenzymes were detected in both yellow and red scald-resistant selections compared with only two in scald-susceptible selections. Similarly, for anodic acidic POX assayed using benzidine, six isoenzymes were detected in both yellow and red scald-resistant selections compared with five in yellow and four in red susceptible selections. Ten SOD isozymes were detected in scald-resistant yellow-fruited selections compared with only five faint bands in scald-susceptible selections, but similar patterns were not detectable for red-fruited selections. Differences in the presence of various isoenzymes for CAT and APX were also detected among the selections, but associations with scald susceptibility were also affected by fruit color or were inconsistent. The presence or absence of individual isoenzymes may be a better indication of scald resistance or susceptibility than the total enzyme activities. Isoenzyme analyses, especially of POX, could be useful to breeders for the early detection of scald resistance/ susceptibility in apples.
\end{abstract}

The reactive oxygen species (ROS), hydrogen peroxide $\left(\mathrm{H}_{2} \mathrm{O}_{2}\right)$, singlet oxygen, superoxide $\left(\mathrm{O}_{2}^{-}\right)$, and hydroxyl $(\cdot \mathrm{OH})$ radicals, are recognized as important features of plant metabolism and in plant responses to stress (Halliwell and Gutteridge, 1989). While ROS are present in all plants in varying degrees as a result of normal metabolism, their levels in vivo depend on the balance between ROS production and the capacity of the cell to scavenge them. $\mathrm{ROS}$, especially $\mathrm{OH}$, can react with all biological macromolecules causing lipid peroxidation as well as modification to the structure and function of proteins and nucleic acids (Bailly et al., 1996; Halliwell and Gutteridge, 1989). ROS induce the antioxidant defense system of low molecular weight antioxidants (Rao et al., 1996), and enzymes such as peroxidase (POX), catalase (CAT), ascorbate peroxidase (APX), superoxide dismutase (SOD) and glutathione reductase (GR) (Alscher et al., 2002; Bowler et al., 1992; Shigeoka et al., 2002). SOD dismutates $\mathrm{O}_{2}{ }^{-}$to $\mathrm{H}_{2} \mathrm{O}_{2}$ and $\mathrm{O}_{2}$ in a reaction that is spontaneous and extremely rapid (Van Camp et al., 1994), thus protecting the cells from damage by $\mathrm{O}_{2}^{-}$reaction products. The product $\mathrm{H}_{2} \mathrm{O}_{2}$, which is also a potentially toxic compound, is then reduced to $\mathrm{H}_{2} \mathrm{O}$ by a number of enzymes such as POX, CAT, APX, and GR (Criessen et al., 1994). Although toxic in high concentrations, ROS are also involved as early messenger molecules

This research was supported by Research Grant Award No. US-3165-99R from BARD, The United States-Israel Binational Agricultural Research and Development Fund, and the federal formula funds, regional project NE103.

${ }^{1}$ Permanent address: National Botanical Research Institute, Lucknow, India. ${ }^{2}$ Corresponding author: e-mail cbw3@cornell.edu. in signal transduction cascades activated by several external and developmental stimuli (Bolwell, 1999; Lamb and Dixon, 1997). $\mathrm{H}_{2} \mathrm{O}_{2}$ serves as a signal molecule during various abiotic stresses (Alvarez et al., 1998; Pellinen et al., 2002; Vranová et al., 2002).

The cold stability of antioxidant enzymes and/or the effective response of associated signal transduction pathways to low temperature may be linked to accelerated ageing and death of cells when oxidative stresses are imposed on plant and fruit tissues (Halliwell and Gutteridge, 1989; Prasad et al., 1994; Purvis and Shewfelt, 1993). Rapid generation of ROS has been reported in potato (Solanum tuberosum L.) tubers at low temperature conditions (Kawakami et al., 1999). The role of ROS metabolism in development of postharvest disorders has been reviewed by Watkins and Rao (2003) and includes chilling injury of cucumber (Cucumis sativus L.), asian pear (Pyrus bretschneideri $\mathrm{R}$.), squash (Cucurbita pepo L.) and mandarin (Citrus reticulata Blanco) (Hariyadi and Parkin, 1991; Ju et al., 1994; Sala and Lafuente, 2000; Wang, 1995).

Superficial scald, a physiological disorder of many apple and pear cultivars, develops during prolonged cold storage (Wilkinson and Fidler, 1973), and is thought to be a chilling injury (Watkins et al., 1995). The widely accepted hypothesis for scald development is that the sesquiterpene $\alpha$-farnesene is oxidized in the peel to produce a number of conjugated triene (CT) species (Anet, 1972; Huelin and Coggiola, 1970a, 1970b; Rowan et al., 1995; Whitaker et al., 1997). Free radicals produced during this oxidation may result in disruption, discoloration and death of surface cells (Du and Bram- 
lage, 1993; Huelin and Coggiola, 1970a, b). Scald susceptibility varies greatly by cultivar, but the reason is unknown.

The antioxidant diphenylamine (DPA) is used commercially as a postharvest drench to prevent scald development. However, the involvement of endogenous antioxidant systems in scald development is not well understood. Anet (1974) suggested that scald would not occur if antioxidant concentrations remained adequate to prevent or sufficiently limit the extent of $\alpha$-farnesene oxidation. Ju and Bramlage (1999), however, did not detect any consistent differences in lipid-soluble antioxidant activity between scald-resistant and susceptible cultivars. Du and Bramlage (1994, 1995) found that activities of SOD (total and metalloenzymes), CAT, POX and polyphenol oxidase were not related to expected scald susceptibilities in 'Cortland', 'Delicious' and 'Empire'. However, the incidence of scald even in 'Cortland', the most susceptible tested cultivar, was less than $23 \%$ in those studies, rendering the comparisons between scalded and non-scalded cultivars inconclusive.

We have utilized a seedling population that resulted from a cross between 'White Angel', a crab apple that is resistant to scald, and 'Rome Beauty', a dessert apple that is highly susceptible to scald, to address the possible involvement of antioxidant enzyme systems in scald susceptibility. These seedlings are hybrids of the same age and were grown under similar environmental conditions. This $\mathrm{F}_{1}$ population is analogous to an $\mathrm{F}_{2}$ cross in other crops due to heterogosity of apple. All selections are siblings and as such are genetically similar and are grown in the same environment. Of 81 trees analyzed, 56 yielded fruit without scald and 25 trees yielded fruit with scald (Weeden, 1993) suggesting that one or a small number of genes may be responsible for scald resistance or susceptibility. Rao et al. (1998) found that lower activities of CAT and POX in several 'White Angel' $x$ 'Rome Beauty' selections were associated with higher $\mathrm{H}_{2} \mathrm{O}_{2}$ pools and lipid peroxidation in the tissue, and with greater scald susceptibility. Collectively, the available data suggest that genetically determined resistance to scald might be enhanced by modifying the ability of apples to metabolize ROS but there has not been any systematic study of the role of antioxidant enzymes in scald formation. Interestingly, Whitaker et al. (2000) found a poor association between CTs and scald development in some 'White Angel' x 'Rome Beauty' selections, suggesting that high accumulation of $\alpha$-farnesene oxidation products may not be necessary for scald development in fruit with severely compromised antioxidative defenses.

The objective of the current study was to fully assess both quantitative and qualitative relationships between antioxidant enzyme activities in differentially scald-sensitive selections of both yellow and red selections from the 'Rome Beauty' $x$ 'White Angel' population. A strength of our approach is that the selections are genetically related, allowing us to correlate scald resistance to a small number of genetic differences segregating within similar genetic backgrounds.

\section{Material and Methods}

Plant material and fruit source. Fruit were collected from $\mathrm{F}_{1}$ yellow and red selections produced as a result of cross between' White Angel' and 'Rome Beauty' growing in the New York State Agricultural Experimental Station, Geneva, N.Y. The trees, each representing a selection, are planted in a row and numbered from 1 to 90 . Selections used in the experiments described here were chosen on the basis of their scald susceptibility (Rao et al., 1998; Whitaker et al., 2000; Watkins, unpublished).

SAMPLING. Fruit were harvested from trees 7, 26, 28, 40, 61, and 65 that produced yellow fruit, and trees 1, 3, 22, 44, 85, and 89 that produced red fruit. The number of fruit available for each selection was variable. Fruit (200 to 300) from each selection were harvested and transported to Ithaca, where 30 fruit of each selection were peeled into liquid nitrogen. The remaining fruit were stored at $0.5{ }^{\circ} \mathrm{C}$, and 30 -fruit samples were removed at $2,6,10$, and 15 weeks and peeled. Peel tissue was extracted immediately for enzyme activity assays, or stored at $-80{ }^{\circ} \mathrm{C}$ for isoenzyme analyses. The remaining fruit (50 to 150 ) were removed from storage on week 20 , and visually scored for scald symptoms after $7 \mathrm{~d}$ at $20^{\circ} \mathrm{C}$.

Enzyme extraction. Peel tissue $(6 \mathrm{~g})$ was ground to a fine powder with a pestle and mortar under liquid nitrogen, added to $200 \mathrm{~mm}$ phosphate buffer ( $\mathrm{pH} 7.8$ ) containing $2 \mathrm{~mm}$ EDTA, 5\% PVP 40 and $1 \mathrm{~mm}$ PMSF [1: $3(\mathrm{w} / \mathrm{v})$ ratio of peel to buffer] and homogenized. For extraction of APX, $5 \mathrm{~mm}$ ascorbate was added to the buffer. The homogenate was centrifuged at $14,000 g_{\mathrm{n}}$ for 30 min at $4{ }^{\circ} \mathrm{C}$. The supernatant was aliquoted and stored at $-80{ }^{\circ} \mathrm{C}$ for subsequent protein and enzyme assays. Total soluble proteins were estimated according to Bradford (1976). Enzyme activities based on total protein were measured spectrophotometrically (Genesys spectrophotometer 5, Rochester, N.Y.) using methods specific to each enzyme as described below. All enzyme assays were performed at $25^{\circ} \mathrm{C}$.

Measurement of SOD aCtIVITY. SOD activity was measured according to Beauchamp and Fridovich (1971) with some modifications. One milliliter of assay mixture contained $100 \mathrm{~mm}$ sodium phosphate buffer ( $\mathrm{pH} 7.8), 57 \mu \mathrm{M}$ nitroblue tetrazolium (NBT), $0.025 \%$ of Triton-X-100, 0.11 mm of EDTA, $0.01 \mathrm{~m}$ methionine, 1.3 $\mu \mathrm{M}$ riboflavin and $50 \mu \mathrm{g}$ of total protein. The reaction was initiated by illuminating the assay mixture with fluorescent lights. After $7 \mathrm{~min}$, the reaction was stopped by removing the light source. A control tube with assay mixture and enzyme was kept in the dark, while another tube without enzyme was kept in light to serve as control for the reduction of NBT by light. The absorbance of the reaction was read at $560 \mathrm{~nm}$. Activity of SOD is reported as NBT reduction in light without enzyme minus NBT reduction with enzyme. One unit of enzyme activity is defined as the amount of enzyme required to inhibit the NBT reduction by $50 \%$ under the assay conditions. SOD data are presented as units of activity per mg protein.

Measurement of POX ACTIVITY. Total POX activity was measured using guaiacol as substrate following the method of Rao et al. (1996) with some modifications. The assay mixture contained $100 \mathrm{~mm}$ phosphate buffer ( $\mathrm{pH}$ 6.8) with $2.7 \mathrm{~mm}$ guaiacol and 4 $\mathrm{mm}$ of $\mathrm{H}_{2} \mathrm{O}_{2}$. The reaction was initiated by the addition of $50 \mu \mathrm{g}$ of total protein, and changes in absorbance at $470 \mathrm{~nm}$ were recorded for a period of $10 \mathrm{~min}$. Activity is expressed as change in optical density (OD) at $470 \mathrm{~nm} \cdot \mathrm{mg}^{-1}$ protein.

Measurement OF APX ACTIVITY. APX activity was determined using the method described by Nakano and Asada (1981). The assay mixture contained $90 \mathrm{~mm}$ potassium phosphate buffer $(\mathrm{pH}$ 7.0), $0.1 \mathrm{~mm}$ EDTA, $0.65 \mathrm{~mm}$ ascorbate and $1 \mathrm{~mm} \mathrm{H}_{2} \mathrm{O}_{2}$. The reaction was initiated by adding $50 \mu \mathrm{g}$ of protein. APX activity was determined by following the $\mathrm{H}_{2} \mathrm{O}_{2}$ dependent decomposition of ascorbate at $290 \mathrm{~nm}$.

Measurement of CAT aCtivity. CAT activity was measured according to Aebi (1983). The reaction mixture contained $50 \mathrm{~mm}$ phosphate buffer ( $\mathrm{pH} 7.0$ ), $2 \mathrm{~mm} \mathrm{H}_{2} \mathrm{O}_{2}$ and 1 mm EDTA. The reaction was initiated by the addition of $50 \mu \mathrm{g}$ total protein and $\mathrm{H}_{2} \mathrm{O}_{2}$ oxidation was measured at $240 \mathrm{~nm}$ using the extinction coefficient of $\mathrm{H}_{2} \mathrm{O}_{2}$. Activity was expressed as $\mu \mathrm{mol} \mathrm{H}_{2} \mathrm{O}_{2} / \mathrm{min} / \mathrm{mg}$ protein.

ISOENZYME ANALYSES. Protein for the analysis of different isoenzymes was obtained from frozen peel tissues that were ground 
to a fine powder with a pestle and mortar under liquid nitrogen. The resultant extract was then homogenized with 1:2 (w/v) ratio of peel to buffer (including $5 \mathrm{~mm}$ ascorbate for APX as described above). The supernatant was subjected to $65 \%$ ammonium sulfate precipitation after centrifugation at $14,000 g_{n}$ at $4{ }^{\circ} \mathrm{C}$. The pellet was then re-suspended in extraction buffer. The suspension was again centrifuged and the supernatant passed through a Sephadex $\mathrm{G} 25$ column. The protein fractions were concentrated using dialysis bags ( $8 \mathrm{kDa}$ cutoff) in glycerol, and stored at $-80^{\circ} \mathrm{C}$ until used for isoenzyme analysis.

All isoenzymes were separated using $8 \%$ separating and $4 \%$ stacking polyacrylamide native gels. An equal amount $(50 \mu \mathrm{g})$ of protein was loaded into each lane and electrophoresis carried out at $4{ }^{\circ} \mathrm{C}$ under nondenaturing conditions as described by Laemmli (1970), except that SDS was omitted. Following electrophoretic separation, the gels were stained for different isoenzymes. Gels were scanned using alpha imager software (Alpha Imager 2200, Alexandria, Va).

POX isoenzymes were visualized by incubating the gels in $50 \mathrm{~mm}$ phosphate buffer ( $\mathrm{pH} 6.5$ ) with $4 \mathrm{~mm} \mathrm{H}_{2} \mathrm{O}_{2}$ and $2.7 \mathrm{~mm}$ guaiacol for 25 min in dark. For acidic or anodic POX the gels were stained according to Kochhar et al. (1979) using a saturated solution of diamino benzidine dissolved in dimethyl formamide and $4 \mathrm{~mm} \mathrm{H}_{2} \mathrm{O}_{2}$ in $50 \mathrm{~mm}$ sodium acetate buffer ( $\mathrm{pH}$ 5.6). The gels were incubated in the dark for 15 to $20 \mathrm{~min}$ on a shaker. In both types of assays, the gels were washed with double distilled water to stop the reactions and the gels were scanned using alpha imager software (Alpha Imager 2200, Alexandria, Va.).

SOD isoenzymes were stained using $2.5 \mathrm{~mm}$ NBT for $25 \mathrm{~min}$, followed by incubation in $50 \mathrm{~mm}$ phosphate buffer ( $\mathrm{pH} 7.8$ ) containing $28 \mathrm{~mm}$ of riboflavin and $28 \mathrm{~mm}$ of N,N,N',N'-tetramethylethylenediamine (TEMED). The gels were illuminated for $10 \mathrm{~min}$ using fluorescent lighting (Beauchamp and Fridovich, 1971).

The APX isoenzyme assay was initiated by first pre-running the gels with the buffer containing $3 \mathrm{~mm}$ ascorbate. Electrophoresis of protein samples was carried out in $100 \mathrm{~mm}$ phosphate buffer containing $2 \mathrm{~mm}$ ascorbate for $15 \mathrm{~min}$. After a brief wash, the gels were transferred to a separate container and developed in $100 \mathrm{~mm}$ phosphate buffer containing $4 \mathrm{~mm}$ ascorbate and $2 \mathrm{~mm} \mathrm{H}_{2} \mathrm{O}_{2}$ for $20 \mathrm{~min}$. The gels were kept in the dark under continuous shaking. After a brief washing, the gels were submerged in $50 \mathrm{~mm}$ phosphate buffer (pH 7.8), $28 \mathrm{~mm}$ TEMED and $2.5 \mathrm{~mm}$ NBT solution for another $15 \mathrm{~min}$ with gentle agitation. Appearance of colorless bands against a blue background indicated APX activity (Mittler and Zilinskas, 1993).

CAT isoenzyme activities were visualized using the method of Woodbury et al.(1971) with modifications. The gels were incubated in $5 \mathrm{mM} \mathrm{H}_{2} \mathrm{O}_{2}$ for $30 \mathrm{~min}$ at room temperature. After $30 \mathrm{~min}$ the gels were washed with distilled water and the activity was stained with $0.5 \%$ ferric chloride and $0.5 \%$ potassium ferricyanide solution

Table 1. Superficial scald incidence (\%) in the red- and yellow-fruited 'White Angel' $x$ 'Rome Beauty' selections after storage at $0.5^{\circ} \mathrm{C}$ for 20 weeks plus $7 \mathrm{~d}$ at $20^{\circ} \mathrm{C}$.

\begin{tabular}{lcccc}
\hline \multicolumn{2}{c}{ Yellow } & & \multicolumn{2}{c}{ Red } \\
\cline { 5 - 5 } Tree no. & Scald $(\%)$ & & Tree no. & Scald $(\%)$ \\
\hline 7 & 0 & 1 & 0 \\
26 & 0 & 3 & 0 \\
28 & 0 & 22 & 0 \\
40 & 100 & 44 & 98 \\
61 & 55 & 85 & 51 \\
65 & 100 & 89 & 63 \\
\hline
\end{tabular}

while on a shaker. CAT activity appeared as blue bands against a green background.

All the enzyme assays and isoenzyme gels were repeated four times, with consistent results each time.

\section{Results}

SCALD INCIDENCE. Apples from three each of the red and yellow selections developed scald during storage (Table 1). These selections provided contrasting susceptible and resistant fruit types within each color category for further study.

ENZYME ACTIVITIES. Changes in SOD activity over time varied greatly in the yellow-fruited selections compared with the redfruited selections (Fig. 1A). In five of the six yellow selections tested, SOD activity decreased between harvest and week 2 , but then activities increased afterwards. This increase was highest in the scald-resistant yellow \#7 and \#26, and lowest in the scald-resistant yellow \#28 and scald-susceptible yellow \#40. In contrast, SOD activities remained low, or stayed the same during storage, in the red-fruited selections, irrespective of scald susceptibility.

POX activities of the yellow \#7 and red \#85 selections, which were resistant and susceptible to scald development, respectively, were markedly higher than activity in the other selections (Fig. 1B). Activities of POX slightly increased by week 10 in several selections, but remained low in resistant yellow \#26 and red \#1, and susceptible red \#89. There was no clear correlation between total POX activity and scald resistance or susceptibility.

APX activities of the yellow-fruited selections fluctuated during storage with no consistent pattern between scald-resistant and susceptible selections (Fig. 1C). In contrast, two (\#44 and \#85) of the three scald-susceptible red-fruited selections had higher APX activities, while activities of all resistant (yellow and red) selections were low.

CAT activity of yellow-fruited selections generally declined during the first few weeks of storage, but then increased, most markedly in the scald-resistant selections at week 10 (Fig 1D). Activities of the red-fruited selections fluctuated during storage with no consistent pattern between scald-resistant and susceptible selections.

ISOENZYME PATTERNS OF THE ANTIOXIDANT ENZYMES. For detailed isoenzyme analyses, we chose to examine yellow \#7 and \#65, and red \#1 and \#44, as examples of scald-resistant and susceptible selections for each fruit skin color group respectively.

Ten distinct SOD isoenzymes were visualized in peel extracts from the yellow scald-resistant selection as compared with the five bands present in the scald-susceptible selection (Fig. 2). The presence of these isoenzymes generally was consistent during storage, with few changes in abundance or activity occurring. In contrast, it was difficult to visualize distinct isoenzymes in the red selections. Five isoenzymes could be seen at harvest and these were either less abundant or had lower activity at 2 and 6 weeks in the resistant selection. They were indiscernible in the susceptible selection.

POX activity on native gels was detected using guaiacol (Fig. 3) or benzidine (Fig. 4). Using guaiacol, the same substrate used in total enzyme activity assays, the number of different isoenzymes varied in scald-resistant and scald-susceptible selections. In both yellow- and red-fruited scald-resistant selections, four isoperoxidases were detected, whereas only two were present in scald-susceptible selections (Fig. 3). These isoenzymes were present at harvest and after 2 and 6 weeks of storage. With benzidine staining, six distinct isoenzymes were observed at harvest and at 2 and 6 weeks of storage in both yellow and red scald resistant selections as compared 

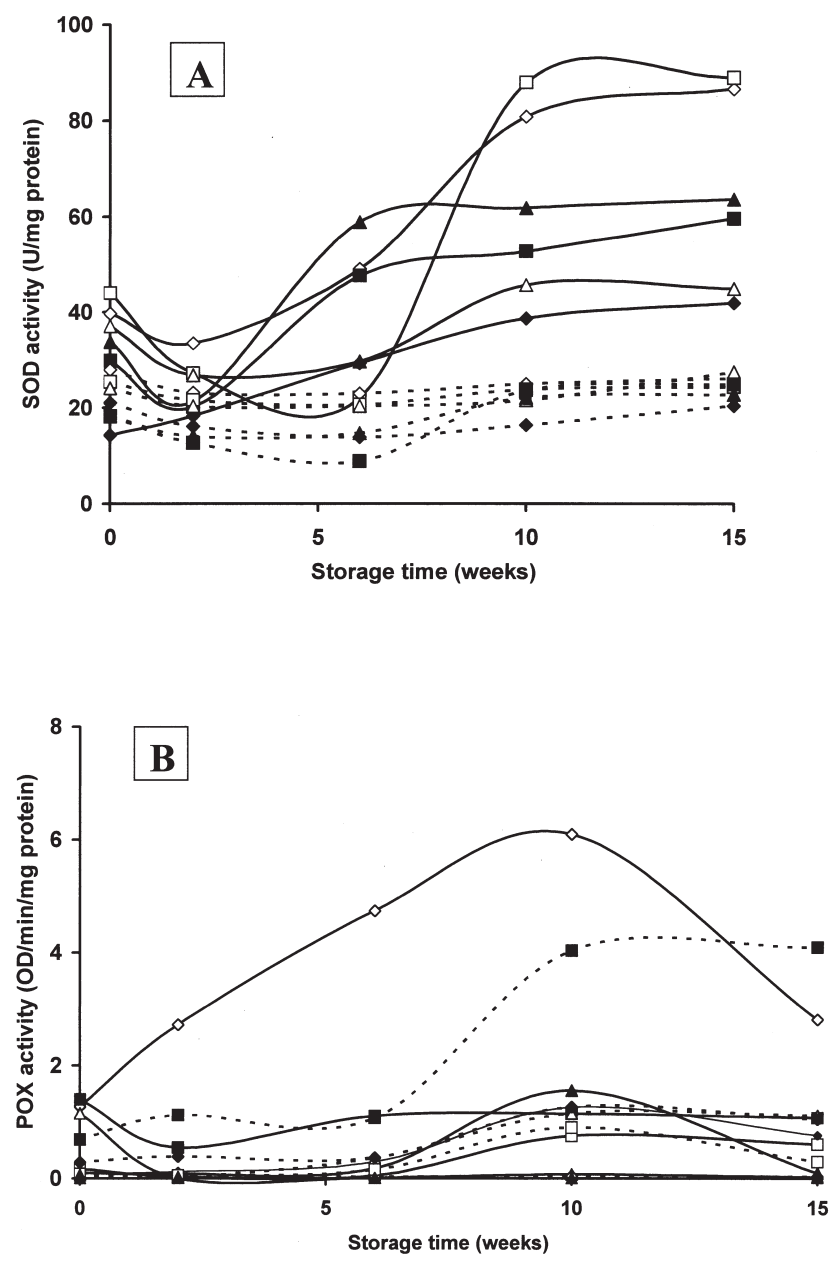

with four in the susceptible yellow-fruited selections and three in red susceptible selections (Fig. 4).

Three CAT isoenzymes were detected in the yellow-fruited scald-resistant selection at harvest and at week 2 but only two were present at week 6 . Only two CAT isoenzymes were observed at all time points in the yellow scald-susceptible selection (Fig. 5). However, only one isoenzyme band was present consistently at all times in both the scald-resistant and susceptible red selections.

While three isoenzymes with APX activity could be seen on native gels for both the yellow scald-resistant and susceptible selections, only two bands were seen in the red scald-resistant

\section{Yellow}

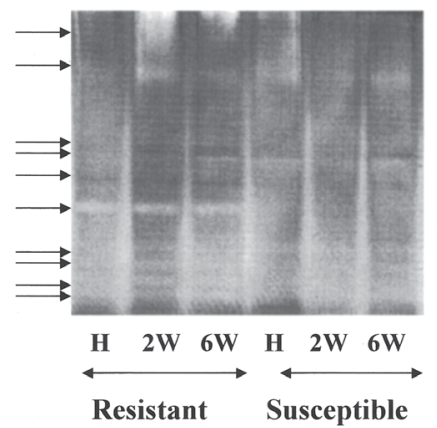

Red

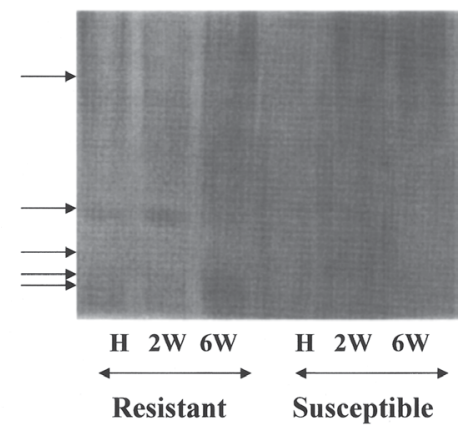

Fig. 2. Activity gels for superoxide dismutase extracted from yellow- and redfruited 'White Angel'x 'Rome Beauty' selections that are resistant or susceptible to superficial scald development. Extracts were obtained from skin of fruit at harvest $(\mathrm{H})$ and during storage at $0.5^{\circ} \mathrm{C}$ for $2(2 \mathrm{~W})$ and $6(6 \mathrm{~W})$ weeks. Arrows identify the bands representing individual isoenzymes.
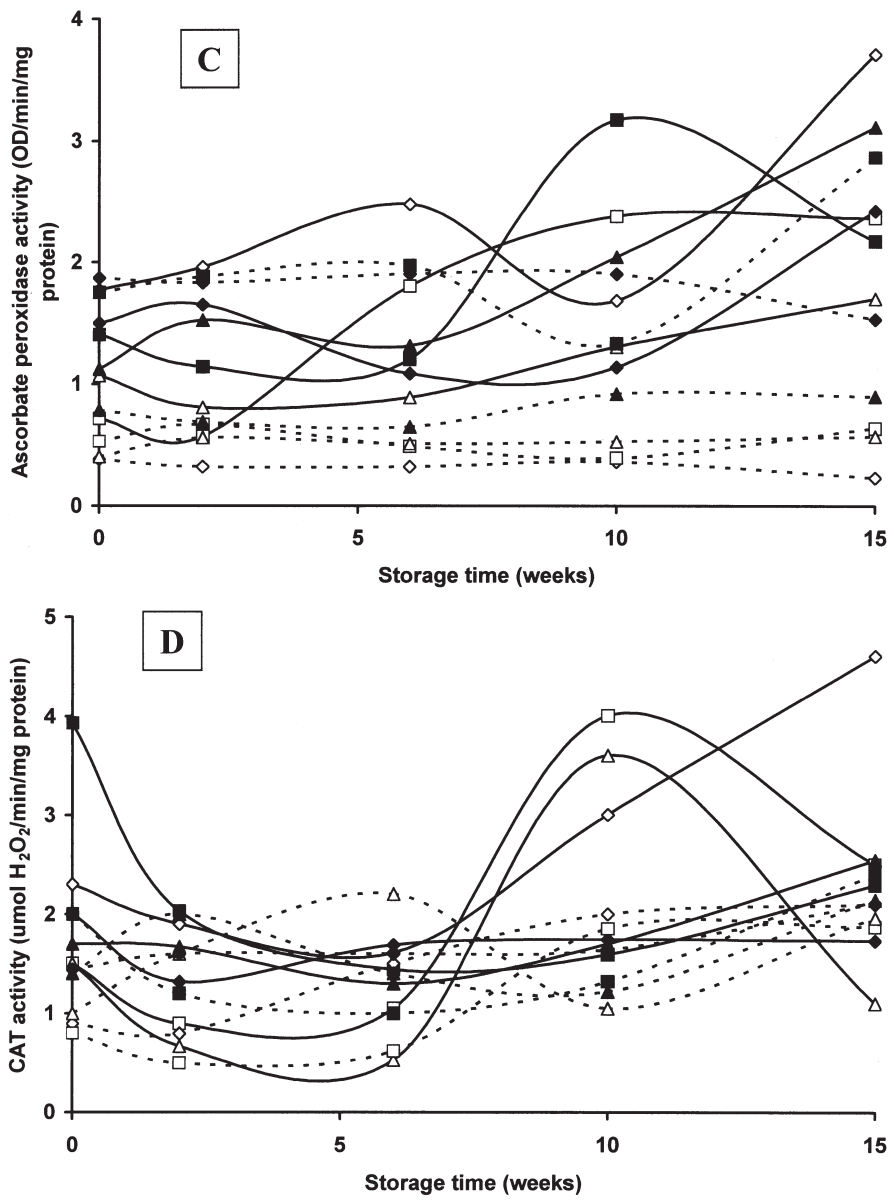

Fig. 1 Specific activities of SOD (A), POX (B), APX (C) and CAT (D) in peel extracts from yellow- and red-fruited 'White Angel' $x$ 'Rome Beauty' selections during storage at $0.5^{\circ} \mathrm{C}$ for 15 weeks. Scald resistant and susceptible selections are indicated by open and closed symbols, respectively. The selections are yellow (solid lines) $7(\diamond), 26(\square), 28(\Delta), 40(\diamond), 61(\square), 65(\mathbf{\Delta})$, and red (broken lines) $1(\diamond), 3(\square), 22(\Delta), 44(\bullet), 85(\square)$, and $89(\mathbf{\Delta})$.
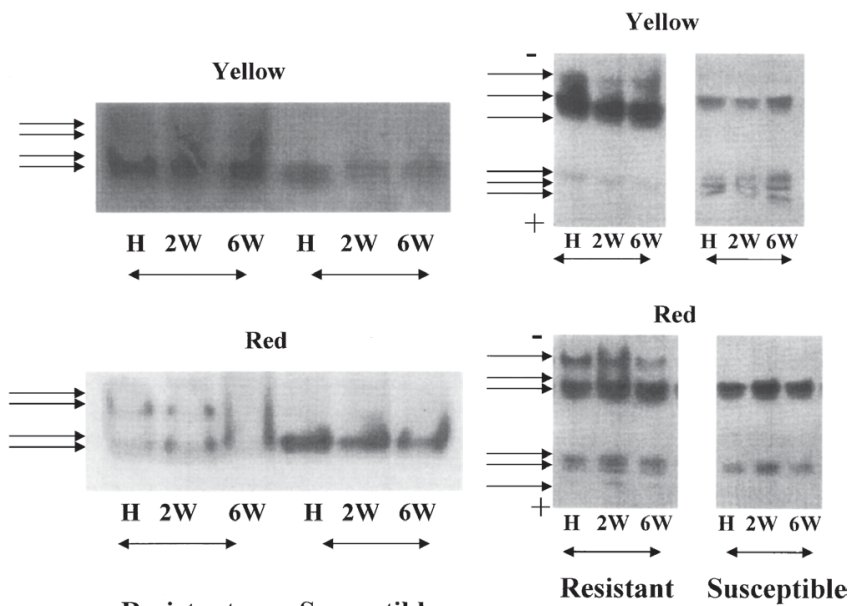

Resistant Susceptible

Fig. 3. Activity gels for guaiacol-dependent peroxidase extracted from yellow- and red-fruited 'White Angel' $x$ 'Rome Beauty' selections that are resistant or susceptible to superficial scald development. Extracts were obtained from skin of fruit at harvest $(\mathrm{H})$ and during storage at $0.5^{\circ} \mathrm{C}$ for $2(2 \mathrm{~W})$ and $6(6 \mathrm{~W})$ weeks. Arrows identify the bands representing individual isoenzymes.
Fig. 4. Activity gels for benzidinedependent peroxidase extracted from yellow-and red-fruited 'White Angel' $\mathrm{x}$ 'Rome Beauty' selections that are resistant or susceptible to superficial scald development. Extracts were obtained from skin of fruit at harvest $(\mathrm{H})$ and during storage at $0.5^{\circ} \mathrm{C}$ for $2(2 \mathrm{~W})$ and $6(6 \mathrm{~W})$ weeks. Arrows identify the bands representing individual isoenzymes. 

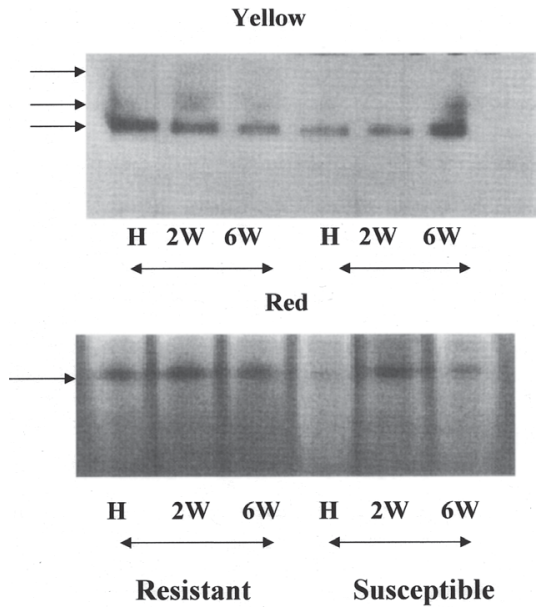

Fig. 5. Activity gels for ascorbate peroxidase extracted from yellow- and red-fruited 'WhiteAngel' x 'Rome Beauty' selections that are resistant or susceptible to superficial scald development. Extracts were obtained from skin of fruit at harvest $(\mathrm{H})$ and during storage at $0.5^{\circ} \mathrm{C}$ for $2(2 \mathrm{~W})$ and $6(6 \mathrm{~W})$ weeks. Arrows identify the bands representing individual isoenzymes.

and susceptible selection (Fig. 6). The number of different isoenzymes did not change by 2 and 6

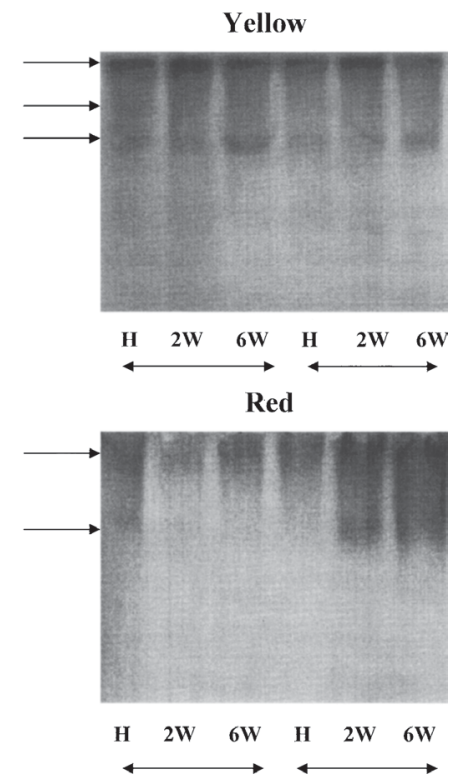

Resistant Susceptible
Fig. 6. Activity gels for catalase extracted from yellow- and redfruited 'White Angel' $x$ 'Rome Beauty' selections that are resistant or susceptible to superficial scald development. Extracts were obtained from skin of fruit at harvest $(\mathrm{H})$ and during storage at $0.5^{\circ} \mathrm{C}$ for $2(2 \mathrm{~W})$ and 6 (6W) weeks. Arrows identify the bands representing individual isoenzymes.

with resistance to scald development. Higher total APX activity in the scald-resistant yellow \#7 selection also is consistent with the possibility that there is an association between antioxidant enzyme activities and scald resistance. However, the scald-susceptible yellow-fruited selections had higherAPX activity, while the scald-resistant redfruited selections had lowerAPX activity. Also, while higher total SOD activity was found in scald-resistant yellow- and red-fruited selections, some susceptible selections had relatively high activities. Anthocyanins can act as antioxidants (Lapidot et al., 1999) and elevated SOD activity in yellow selections could be part of a compensatory mechanism for lower anthocyanin concentrations in yellow fruit selections. In addition, elevated SOD activity during postharvest storage could be a response to chilling conditions that is not related directly to scald per se (Du and Bramlage, 1994; Pinhero et al., 1997; Rao et al., 1998). a hypothesis that higher antioxidant enzyme activities are associated

We did not identify consistent correlations between total antioxidant activity of SOD, POX, APX, or CAT and scald incidence within the different susceptible and resistant 'White Angel' $X$ 'Rome Beauty' selections. High total POX activity in the scald-resistant yellow \#7 selection, but low activities in resistant selections (yellow \#26 and \#28 and red \#1 and \#3) during weeks 2 to 6 do not support

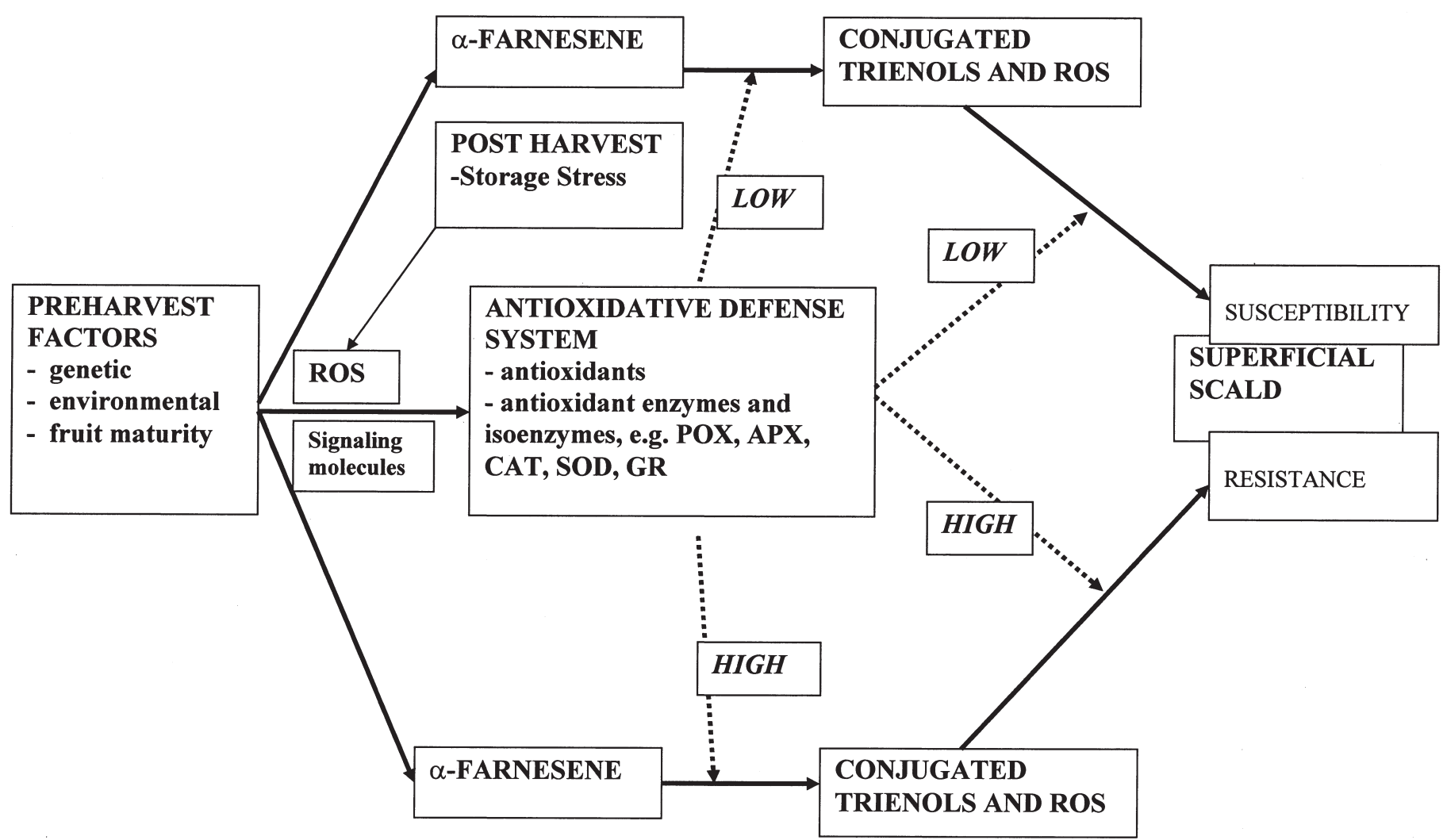

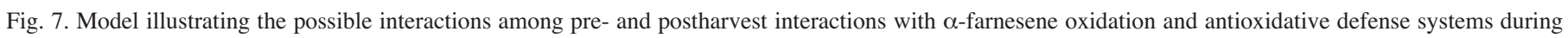
superficial scald development. 
Our results contrast with those of Rao et al. (1998), where higher activities of POX and CAT in combined fruit peel and cortical tissue, both at harvest and during storage, were associated with lower scald susceptibility of 'White Angel' X 'Rome Beauty' selections. Differences of these results compared with those of Rao et al. (1998) may relate to comparisons of fruit chosen within a narrow maturity range as indicted by internal ethylene concentrations in the earlier study.

Although the results on antioxidant enzyme activities do not suggest a clear relationship between antioxidant enzymes and scald resistance, the results do not exclude the involvement of antioxidant systems in scald development in apples. A balance of many factors and coordination of these factors, including antioxidant enzymes, is likely to be involved in disorder development. Coordination between $\mathrm{H}_{2} \mathrm{O}_{2}$-generating SOD and $\mathrm{H}_{2} \mathrm{O}_{2}$-degenerating POX, APX and CAT enzyme activities are necessary for cells to function properly (Creissen et al., 1994; Van Camp et al., 1994). Thus, scald development is unlikely to depend solely on the relative accumulation or degradation of $\mathrm{H}_{2} \mathrm{O}_{2}$.

Study of isoenzymes of several antioxidant enzymes in relation to scald susceptibility, however, suggest that the presence/ absence of specific isoenzymes may play a role in scald-resistance or susceptibility in apples during storage. The evidence supporting this hypothesis is strongest for POX, where the presence of four different isoenzymes in both yellow and red scald-resistant selections (when stained with guaiacol) contrasted to only two in scald-susceptible selections at harvest and after 2 and 6 weeks of storage (Fig. 3). In addition to cathodic peroxidases, three acidic peroxidase isoenzymes that migrated towards the anode $(+)$ and were seen only with benzidine staining (Fig. 4), were observed in all selections except in the red susceptible one. The number of bands was reduced to two and their relative activities differed considerably with respect to both peel color and scald susceptibility. Whereas the three acidic isoperoxidase activities were relatively low in the scald-resistant yellow \#7 selection, but comparatively higher in the scald-susceptible yellow \#65, the reverse was true for red selections. However, it appears that the number of acidic POX isoenzymes is higher overall in the resistant selections, similar to the pattern with the cathodic POX isoenzymes. The importance of POX in many different physiological functions and their use as markers in some plant processes has been described (Gaspar et al, 1991; Kochhar et al., 1982). Isoenzymes of POX may be markers for scald resistance and this possibility is under further investigation in our laboratory.

Associations among the isoenzymes of other antioxidant enzymes and scald incidence are less consistent than for POX. A higher number of isoenzymes of SOD were found in the yellow resistant selection than in the yellow susceptible selection (Fig. 2). However, only a few faint bands of SOD isoenzymes were observed in red selections making distinctions across all selections difficult to discern. Fewer isoenzymes may reflect the comparatively low total SOD activity measured in red selections. Some minor differences were observed in the number of CAT isoenzymes in yellow scald-resistant and susceptible selections at the time of harvest, and after 2 and 6 weeks of storage, but no difference was seen in red scald-resistant and susceptible selections (Fig. 5). APX isoenzymes were either more abundant or had higher relative activity in red scald-susceptible than in red scald-resistant, or yellow scald-resistant and susceptible selections (Fig. 6).

Arelationship between scald susceptibility or resistance of apples and endogenous antioxidant systems (Anet, 1974) is consistent with the $\alpha$-farnesene oxidation hypothesis (Du and Bramlage, 1993).
Our results, however, indicate that any the involvement of antioxidant enzymes in scald resistance in apples is likely to be complex. Variations between scald susceptibility and antioxidant activities are affected by fruit color and selection studied. Also, interactions among enzymes will occur. For example, both total SOD activity and the number of different SOD isoenzymes are elevated in yellow scald-resistant selections. Higher SOD activity would lead to dismutation of superoxide and thus prevent the toxic effect of reactive species such as those generated by oxidation of $\alpha$-farnesene. In contrast, low SOD activity in certain selections would lead to a low formation of peroxides. A low level of peroxides would result in the induction of only low levels of POX activity and cause a dampening of the antioxidant defense system of membranes and cortical tissue or of fruit as a whole. Such tissue would be susceptible to many diseases of fruit that have an oxidative basis.

Susceptibility of apples to superficial scald is affected by genetic, environmental (growing region and seasonal variations), maturity, and other preharvest factors (Emonger et al., 1994). If the $\alpha$-farnesene oxidation hypothesis is correct, then these factors are likely to affect both the production of $\alpha$-farnesene (the potential to induce free radical damage) and the antioxidative defense system. While $\alpha$-farnesene production is required for scald development to occur, its production can vary greatly by cultivar and the rates of production are not always closely associated with scald susceptibility of the fruit (Anet, 1974). Moreover, the absolute amounts of $\alpha$-farnesene produced may be less important than activity of the antioxidant systems (Whitaker et al., 2000). The antioxidant defense system in fruit at harvest will be affected greatly by preharvest factors (Anet 1972; Du and Bramlage, 1999). Scald development is probably a chilling related disorder (Watkins et al., 1995) and we speculate that the role of antioxidant defense system will be critical in the ability of the fruit to withstand cold storage, a period of stress to harvested products that leads to production of ROS and signaling molecules. Irrespective of whether $\alpha$-farnesene production is high or low, high antioxidant activity would result in reduced $\alpha$-farnesene oxidation and resistance against damage caused by CTs and ROS. Conversely, low activity would result in greater $\alpha$-farnesene oxidation and lower resistance to the damaging species. A hypothetical model based on our findings and information from literature is proposed as shown in Fig. 7 which illustrates the possible ways that pre- and postharvest factors could influence the interactions among $\alpha$-farnesene, CTs, antioxidants, antioxidant enzyme activities and their various isoenzymes. A change in threshold of any of these factors due to external or internal stimuli could change the cascade of events leading to scald.

\section{Literature Cited}

Aebi, H.E. 1983. Catalase in vitro. Methods Enzymol. 105:121-126.

Alscher, R.G., N. Erturk, and L.S. Heath. 2002. Role of superoxide dismutases (SODs) in controlling oxidative stress in plants. J. Expt. Bot. 53:1331-1341.

Alvarez, M.E., R.I. Pennell, P.J. Meijer, A. Ishikaawa, R.A. Dixon, and C. Lamb. 1998. Reactive oxygen intermediates mediate a systemic signal network in the establishment of plant immunity. Cell 92:773-784.

AnetE.F.L.J. 1972. Superficial scald, a functional disorder of stored apples. IX. Effect of maturity and ventilation. J. Sci. Food Agr. 23:763-769.

AnetE.F.L.J. 1974. Superficial scald, a functional disorder of stored apples. XI. Apple antioxidants. J. Sci. Food Agr. 25:299-304.

Bailly, C., A. Benamar, F. Corbineau, and D. Come. 1996. Changes in malondialdehyde content and in superoxide dismutase, catalase and glutathione reductase activities in sunflower seeds as related to deterioration during accelerated aging. Physiol. Plant. 97:104-110.

Beauchamp, C. and I. Fridovich. 1971. Superoxide dismutase: Improved 
assay and an assay applicable to acrylamide gels. Anal. Biochem. 44: 276-287.

Bolwell, G.P. 1999. Role of active oxygen species and NO in plant defense responses. Curr. Opinion Plant Biol. Rev. 4:287-94.

Bowler, C., M. Von Montagu, and D. Inze. 1992. Superoxide dismutase and stress tolerance. Annu. Rev. Plant Physiol. Plant Mol. Biol. 43:83-116.

Bradford, M.M. 1976. A rapid and sensitive method for the quantitation of microgram quantities of protein utilizing the principle of protein-dye binding. Anal. Biochem. 72:248-254.

Creissen, G.P., E.A. Edwards, and P.M. Mullineaux. 1994. Glutathione reductase and ascorbate peroxidase, p. 363-364. In: C.H. Foyer and P.M. Mullineaux (eds.). Causes of photo-oxidative stress and amelioration of defense systems in plants. CRC Press, Boca Raton, Fla.

Du, Z. and W.J. Bramlage. 1993. A modified hypothesis on the role of conjugated trienes in superficial scald development on stored apples. J. Amer. Soc. Hort. Sci. 118:807-813.

Du,Z. and W.J. Bramlage. 1994. Superoxide dismutase activities in senescing apple fruit (Malus domestica Borkh.). J. Food Sci. 59:581-584.

Du,Z. and W.J. Bramlage. 1995. Peroxidase activity of apple peel in relation to development of post-storage disorders. HortScience 30:205-209.

Emongor, V.E., D.P. Murr, and E.C. Lougheed. 1994. Preharvest factors that predispose apples to superficial scald. Postharvest Biol. Technol. 4:289-300.

Gaspar, T., C. Penel, D. Hagege, and H. Greppin. 1991. Peroxidases in plant growth, differentiation and development processes, p. 249-280 In: J. Lobarzewski, H. Greppin, C. Penel, and T. Gaspar (eds.). Biochemical molecular and physiological aspects of plant peroxidases. Univ. Geneva, Geneva.

Halliwell, B. and J.M.C. Gutteridge. 1989. Iron and free radical reactions: two aspects of antioxidant protection. Trends Biochem. Sci.11:375.

Hariyadi, P. and K.L. Parkin. 1991. Chilling-induced oxidative stress in cucumber fruit. Postharvest Biol. Technol. 1:33-45.

Huelin, F.E and I.M Coggiola. 1970a. Superficial scald, a functional disorder of stored apples. V. Oxidation of $\alpha$-farnesene and its inhibition by diphenylamine. J. Sci. Food Agr. 21:44-48

Huelin, F.E and I.M Coggiola. 1970b. Superficial scald, a functional disorder of stored apples. VII. Effect of applied $\alpha$-farnesene, temperature and diphenylamine on scald and concentration of autooxidation of $\alpha$ farnesene in the fruit. J. Sci. Food Agr. 21:584-589.

Ju, Z. and W.J. Bramlage. 1999. Phenolics and lipid-soluble antioxidants in fruit cuticle of apples and their antioxidant activities in model systems. Postharvest Biol. Technol. 16:107-118.

Ju, Z.G., Y.B. Yuan, C.L. Liu, C.L., S.M.Zhan, and S.H. Xin. 1994. Effect of low temperature on $\mathrm{H}_{2} \mathrm{O}_{2}$ and brown heart of Chilli and Yali (Pyrus bretschneideri R). Sci. Agr. Sin. 27:77-81.

Kawakami, S., M. Mizuno, and H. Tsuchida. 1999. The defense mechanism against oxidative stress generated in potato tubers during low temperature storage. Plant Peroxidase Nwsltt. 14:125-132.

Kochhar,S., V.K. Kochhar, and S.D. Khanduja. 1979. Changes in the pattern of isoperoxidases during maturation of grape berries of cv. Gulabi as affected by ethephon (2-chloroethyl phosphoric acid). Amer. J. Enol. Viticult. 30:275-277.

Kochhar, S., A.K. Singh, V.K. Kochhar, and T.N. Khoshoo. 1982. Physiological and biochemical basis of male sterility in african marigold. I. Peroxidase activity and its isozyme pattern. Indian J. Biochem. Biophysiol. 19:67-69.

Laemmli, U. K. 1970. Cleavage of structural proteins during the assembly of the head of bacteriophage T4. Nature 227:680-685.

Lamb C. and R.A. Dixon. 1997. The oxidative burst in plant disease resistance. Annu. Rev. Plant Physiol.Plant Mol. Biol. 48: 251-275.

Lapidot,T., S. Harel, B. Akiri, R. Granit, and J. Kanner. 1999. pH-dependent forms of red wine anthocyanins as antioxidants. J. Agr. Food Chem 47:67-70.

Mittler, R and B.A. Zilinskas. 1993. Detection of ascorbate peroxidase activity in native gels by inhibition of the ascorbate dependent reduction of NBT (nitroblue tetrazolium). Anal. Biol. Chem. 212:540-546.
Nakano Y. and K. Asada. 1981. Hydrogen peroxide is scavenged by ascorbate-specific peroxidase in spinach chloroplasts. Plant Cell Physiol. 22: 867-880.

Pellinen, R.I., M.S. Korhonen, A.A. Tauriainen, E.T. Palva, and J. Kangasjarvi. 2002. Hydrogen peroxide activates cell death and defense gene expression in birch. Plant Physiol. 130:549-60.

Pinhero, R.G., M.V. Rao, G. Paliyath, D.P. Murr, and R.A. Fletcher. 1997. Changes in activities of antioxidant enzymes and their relationship to genetic and paclobutrazol-induced chilling tolerance of maize seedlings. Plant Physiol.114:695-704.

Prasad, T.K., M.D. Anderson, and C.R. Stewart. 1994. Acclimation, hydrogen peroxide, and abscisic acid protect mitochondria against irreversible chilling injury in maize seedlings. Plant Physiol. 105:619-627.

Purvis, A.C. and R.L. Shewfelt. 1993. Does the alternative pathway ameliorate chilling injury in senescent plant tissues? Physiol. Plant. 88:712-718.

Rao, M.V., G. Paliyath, and D.P. Ormrod. 1996. UV-B- and ozone induced biochemical changes in antioxidant enzymes of Arabidopsis thaliana. Plant Physiol. 110:125-136.

Rao, M.V., C.B. Watkins, S.K. Brown, and N.F. Weeden. 1998. Active oxygen species metabolism in 'White Angel' $x$ 'Rome Beauty' apple selections resistant and susceptible to superficial scald. J. Amer. Soc. Hort. Sci. 123:299-304.

Rowan, D.D., J. M. Allen., S. Fielder, J.A. Spicer, and M. A. Brimble. 1995. Identification of conjugated triene oxidation products of $\alpha$-farnesene in apple skin. J. Agr. Food Chem. 43:2040-2045.

Sala J.M. and M.T. Lafuente. 2000. Catalase enzyme activity is related to tolerance of mandarin fruits to chilling. Postharvest Biol. Technol. 20:81-89.

Shigeoka, S., T. Tshikawa, M. Tamoi, Y. Miyagawa, T. Takeda, Y., Yabuta, and K. Yoshimura. 2002. Regulation and function of ascorbate peroxidase isoenzymes. J. Expt. Bot. 53:1305-1319.

Van Camp W., M. Van Montagu, and D. Inze. 1994. Superoxide dismutase, p. 318-344. In: C.H. Foyer and P.M. Mullineaux (eds.). Causes of photooxidative stress and amelioration of plant defense system. CRC Press, Boca Raton, Fla.

Vranová, E., D. Inzé, and F. Van Bresuegem. 2002. Signal transduction during oxidative stress. J. Expt. Bot. 53:1227-1236.

Wang, C.Y. 1995. Effect of temperature preconditioning on catalase, peroxidase, and superoxide dismutase in chilled zucchini squash. Postharvest Biol. Technol. 5:67-76

Watkins, C.B., W.J. Bramlage, and B.A. Cregoe. 1995. Superficial scald of 'Granny Smith' apples is expressed as a typical chilling injury. J. Amer. Soc. Hort. Sci. 120:88-94.

Watkins, C.B. and M.V. Rao. 2003. Genetic variation and prospects for genetic engineering of horticultural crops for resistance to oxidative stress induced by postharvest conditions, p. 199-224. In: M. Hodges (ed.). Postharvest oxidative stress in horticultural crops. Food Products Press, The Haworth Press, Binghamton, N.Y.

Weeden, N.F. 1993. Genetic control of apple storage scald. N.Y. Fruit Quart. (Winter):12-13.

Whitaker, B.D., T. Solomos, and D.J. Harrison. 1997. Quantification of $\alpha$-farnesene and its trienol oxidation products from apple peel by $\mathrm{C}_{18^{-}}$ HPLC with UV detection. J. Agr. Food Chem. 45:760-765.

Whitaker, B.D., J.F. Nock, and C.B. Watkins. 2000. Peel tissue $\alpha$-farnesene and conjugated trienol concentrations during storage of 'White Angel' $x$ ' Rome Beauty' hybrid apple selections susceptible and resistant to superficial scald. Postharvest Biol. Technol. 20:231-241.

Wilkinson, B.G. and J.C. Fidler. 1973. Injuries caused by incorrect concentrations of carbon dioxide and/or oxygen, p. 81-87. In: J.C. Fidler, B.G. Wilkinson, K.L. Edney, and R.O. Sharples (eds.). The biology of apple and pear storage. Res. Rev. 3. Commonwealth. Bur. Hort. Plantation Crops, East Malling, England.

Woodbury W., A.K. Spencer, and M.A. Stahman. 1971. An improved procedure for using ferricyanide for detecting catalase isozymes. Anal. Biochem. 44:301-305. 